\title{
Streptomyces samsunensis sp. nov., a member of the Streptomyces violaceusniger clade isolated from the rhizosphere of Robinia pseudoacacia
}

\author{
Correspondence \\ Nevzat Sahin \\ nsahin@omu.edu.tr
}

\author{
Anıl Sazak, ${ }^{1}$ Nevzat Şahin, ${ }^{1}$ Kıymet Güven, ${ }^{2}$ Kamil Işık $^{1}$ \\ and Michael Goodfellow ${ }^{3}$ \\ ${ }^{1}$ Department of Biology, Faculty of Art and Science, Ondokuz Mayıs University, \\ 55139 Kurupelit-Samsun, Turkey \\ ${ }^{2}$ Department of Biology, Faculty of Science, Anadolu University, Eskisehir, Turkey \\ ${ }^{3}$ Department of Biology, University of Newcastle, Newcastle upon Tyne NE1 7RU, UK
}

\begin{abstract}
The taxonomic position of a Streptomyces isolate, strain $\mathrm{M} 1463^{\top}$, recovered from the rhizosphere of Robinia pseudoacacia was established in a polyphasic study. The organism had chemical and morphological markers that were consistent with its classification in the Streptomyces violaceusniger clade. This assignment was confirmed by $16 \mathrm{~S}$ rRNA gene sequence data, which also showed that the strain formed a distinct subclade together with Streptomyces malaysiensis DSM $41697^{\top}$. However, the two strains were readily distinguished on the basis of DNA relatedness and phenotypic data. The combined genotypic and phenotypic data show that strain $M 1463^{\top}$ should be recognized as a representative of a novel species in the Streptomyces violaceusniger clade, for which the name Streptomyces samsunensis sp. nov. is proposed. The type strain of $S$. samsunensis is $\mathrm{M}_{1463^{\top}}$ (=DSM $42010^{\top}=\mathrm{NRRL} B-24803^{\top}$ ).
\end{abstract}

Taxonomic relationships within the genus Streptomyces have been clarified and extended by the application of genotypic and phenotypic methods to representatives of species with validly published names and putatively novel species (Goodfellow et al., 1992; Manfio et al., 1995; Anderson \& Wellington, 2001; Kumar \& Goodfellow, 2008). It is now apparent that the type strains of many species of the genus Streptomyces can be assigned to distinct multimembered species groups, as exemplified by species classified in the Streptomyces albidoflavus (Lanoot et al., 2005), Streptomyces griseus (Liu et al., 2005), Streptomyces violaceoruber (Duangmal et al., 2005), Streptomyces violaceusniger (Sembiring et al., 2000) and Streptomyces yeochonensis (Xu et al., 2006) 16S rRNA gene clades. Members of the $S$. violaceusniger clade typically form a greyish aerial spore mass and a greyish yellow substrate mycelium on oatmeal agar, produce aerial hyphae that differentiate into spiral chains of rugose ornamented spores (Sembiring et al., 2000; Goodfellow et al., 2007; Kumar \& Goodfellow, 2008), give a characteristic amplification product with taxon-specific primers (Kumar et al., 2007), and produce the metabolites elaiophylin, geldanamycin, nigericin and an uncharacterized polyene (Ward \& Goodfellow, 2004).

The GenBank/EMBL/DDBJ accession number for the $16 \mathrm{~S}$ rRNA gene sequence of Streptomyces samsunensis M1463 ${ }^{\top}$ is EU077190.
The S. violaceusniger clade currently encompasses species with validly published names and that are mainly circumscribed using a combination of DNA-DNA relatedness and phenotypic data (Labeda \& Lyons, 1991; Sembiring et al., 2000; Goodfellow et al., 2007; Kumar \& Goodfellow, 2008). Members of the clade have been isolated from geographically diverse soils (Al-Tai et al., 1999; Saintpierre et al., 2003; Hayakawa et al., 2004) and from rhizosphere and non-rhizosphere soils (Sembiring et al., 2000). PCR amplification of DNA extracted from marine and terrestrial samples using $S$. violaceusniger cladespecific primers has provided evidence for the widespread distribution of novel members of the clade in natural habitats (Kumar et al., 2007).

In the course of a screening programme designed to recover novel streptomycetes from rhizosphere soil, a strain, designated $\mathrm{M} 1463^{\mathrm{T}}$, was shown to have activity against several microbial targets and to have colonial and morphological features suggesting that it may be a member of the S. violaceusniger clade. The aim of the present study was to determine the taxonomic status of the isolate using a polyphasic taxonomic approach. The resultant data indicate that the organism should be classified as a representative of a novel species of the genus Streptomyces.

Strain $\mathrm{M} 1463^{\mathrm{T}}$ was isolated after 14 days of incubation at $28{ }^{\circ} \mathrm{C}$ from the rhizosphere of Robinia pseudoacacia by plating soil suspensions onto starch-casein agar (Küster, 


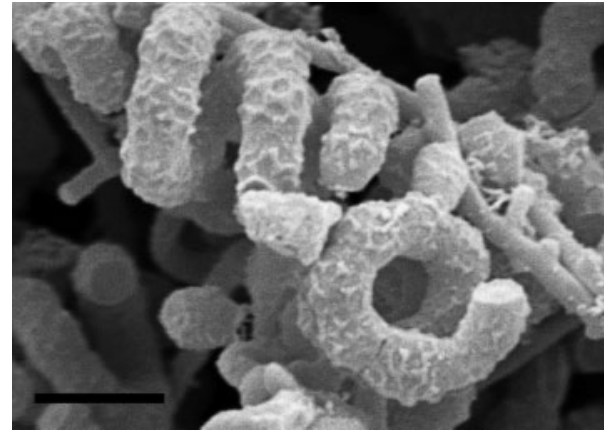

Fig. 1. Scanning electron micrograph showing spiral chains of rugose ornamented spores of strain $\mathrm{M} 1463^{\top}$ grown on inorganic salts-starch agar (ISP 4 medium) at $28{ }^{\circ} \mathrm{C}$ for 14 days. Bar, $2 \mu \mathrm{m}$.

1959) supplemented with filter-sterilized cycloheximide $\left(50 \mu \mathrm{g} \mathrm{ml}^{-1}\right)$, nystatin $\left(50 \mu \mathrm{g} \mathrm{ml}^{-1}\right)$ and rifampicin $\left(0.5 \mu \mathrm{g} \mathrm{ml}^{-1}\right)$. The organism was maintained on slopes of oatmeal agar (DSMZ, 1998) and as mycelial fragments and spores in glycerol $(20 \%, \mathrm{v} / \mathrm{v})$ at $-20^{\circ} \mathrm{C}$. Biomass for chemotaxonomic and molecular systematic studies was grown in shake flasks of tryptic soy broth at 160 r.p.m. at $28{ }^{\circ} \mathrm{C}$ for 14 days, checked for purity and harvested by centrifugation. Cells for the chemotaxonomic tests were washed twice in distilled water and freeze-dried; cells for molecular systematic procedures were washed in $\mathrm{NaCl} /$ EDTA buffer (0.1 M EDTA, $0.1 \mathrm{M} \mathrm{NaCl}$; $\mathrm{pH} \mathrm{8.0)}$ and stored at $-20{ }^{\circ} \mathrm{C}$ until required.
The isolate was grown on oatmeal agar (ISP 3; Shirling \& Gottlieb, 1966) and peptone-yeast extract-iron agar (ISP 6; Shirling \& Gottlieb, 1966) plates at $28{ }^{\circ} \mathrm{C}$ for 14 and 4 days, respectively. The oatmeal agar plates were examined by eye to determine aerial spore mass colour, substrate mycelium pigmentation and the colour of any diffusible pigment using National Bureau of Standards Color Name Charts (Kelly, 1958; National Bureau of Standards, 1964). The peptone-yeast extract-iron agar plates were examined to see whether the strain produced melanin pigments. Sporechain morphology and spore-surface ornamentation were determined by examining gold-coated dehydrated specimens using a Cambridge Stereoscan 240 instrument. The strain was also probed using the $S$. violaceusniger cladespecific oligonucleotide primers described by Kumar et al. (2007). The organism formed a greyish aerial spore mass, which later turned black, a greyish yellow substrate mycelium and no diffusible pigment on oatmeal agar; it did not produce melanin pigments on peptone-yeast extract-iron agar. It formed spiral chains of rugose ornamented spores (Fig. 1) and gave a PCR amplification product characteristic of members of the $S$. violaceusniger clade. All of these properties indicated that isolate $\mathrm{M} 1463^{\mathrm{T}}$ is a bona fide member of the $S$. violaceusniger clade (Goodfellow et al., 2007; Kumar \& Goodfellow, 2008).

Genomic DNA extraction and PCR-amplification of the 16S rRNA gene of strain M1463 ${ }^{\mathrm{T}}$ were carried out with minor modifications of the procedure used by Pitcher et al. (1989), as described by Sembiring et al. (2000). The amplified fragments were purified with QIAquick purifica-
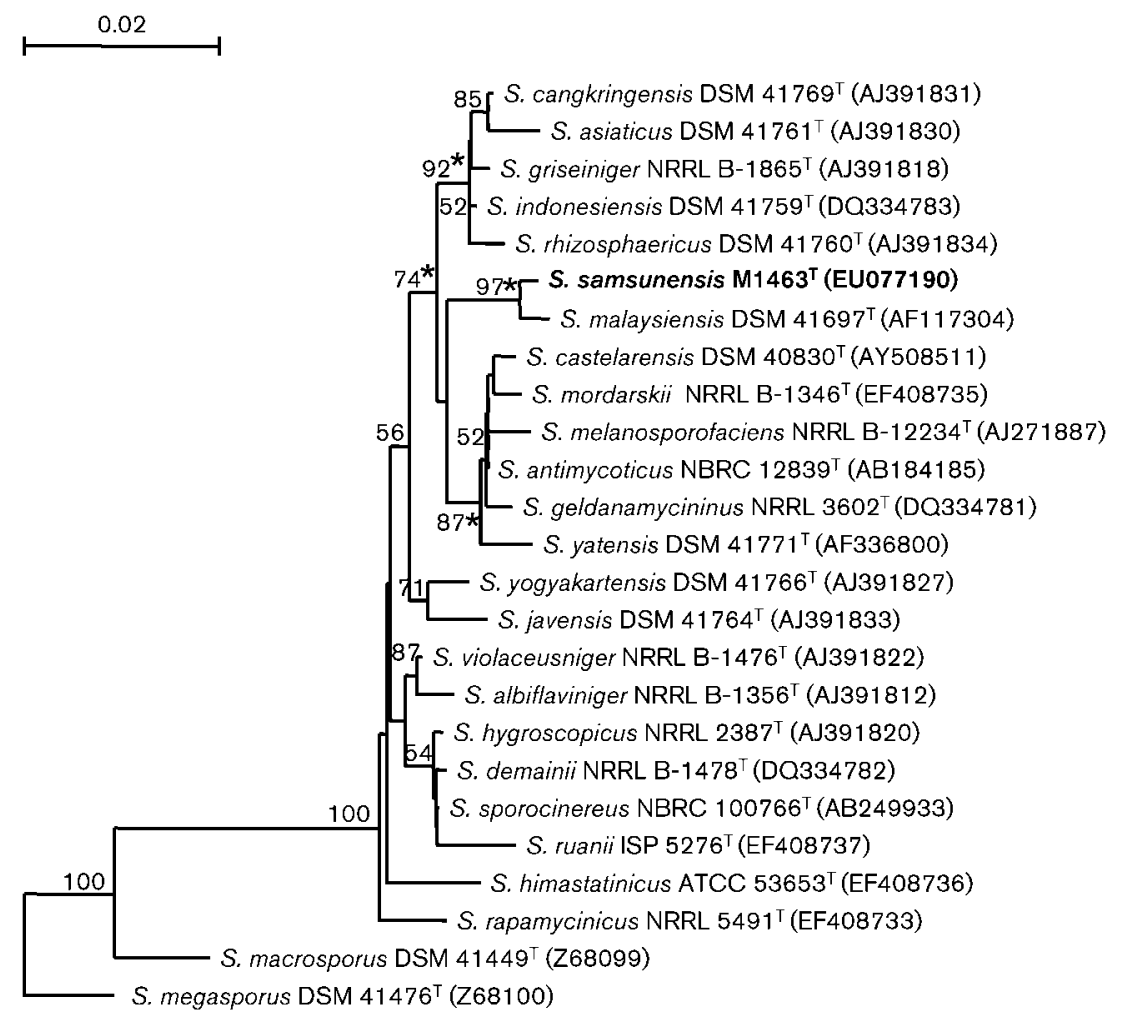

Fig. 2. Neighbour-joining tree based on $1438 \mathrm{bp}$ of $16 \mathrm{~S}$ rRNA gene sequences showing the position of strain $M 1463^{\top}$ on the $S$. violaceusniger gene tree. The asterisks denote branches that are conserved when using the least-squares, maximum-likelihood and maximum-parsimony tree-making algorithms. The numbers at the nodes indicate levels of bootstrap support (\%) based on a neighbour-joining analysis of 1000 resampled datasets; only values $>50 \%$ are cited. GenBank accession numbers are given in parentheses. Bar, 0.02 substitutions per site. 
tion kits (Qiagen) and sequenced directly using ABI Prism BigDye Terminator v2.0 Cycle Sequencing kits (Applied Biosystems) and standard oligonucleotide primers (Lane, 1991; Chun \& Goodfellow, 1995). Sequencing gel electrophoresis was performed and the nucleotide sequences were obtained automatically by using an Applied Biosystems DNA sequencer (ABI PRISM 310) and software provided by the manufacturer. The resultant $16 \mathrm{~S}$ rRNA gene sequence was aligned against corresponding sequences of members of the $S$. violaceusniger clade retrieved from GenBank/EMBL/DDBJ using the PHYDIT program (Chun, 1995). Unrooted phylogenetic trees were inferred using the least-squares (Fitch \& Margoliash, 1967), maximumlikelihood (Felsenstein, 1993) and neighbour-joining (Saitou \& Nei, 1987) tree-making algorithms drawn from the PHYLIP 3.5c suite of programs (Felsenstein, 1993). Evolutionary distance matrices were generated for the neighbour-joining and least-squares methods, as described by Jukes \& Cantor (1969). The resultant tree topologies were evaluated by bootstrap analysis (Felsenstein, 1985) with 1000 resamplings from the neighbour-joining dataset using the SEQBOOT and CONSENSE programs from the PHYLIP package (Felsenstein, 1993).

Comparison of the almost complete 16S rRNA nucleotide sequence obtained for strain $\mathrm{M} 1463^{\mathrm{T}}$ (1478 nt) with corresponding sequences of type strains of species classified in the S. violaceusniger clade showed that the isolate formed a well-delineated subclade with $S$. malaysiensis DSM $41697^{\mathrm{T}}$; the taxonomic status of the subclade was supported by all of the tree-making algorithms and by a bootstrap value of $97 \%$ in the neighbour-joining analysis (Fig. 2). Identification of the closest phylogenetic neighbours and calculation of pairwise 16S rRNA gene sequence similarities were provided using the EzTaxon server (http:// www.eztaxon.org/; Chun et al., 2007). The two strains shared a $16 \mathrm{~S}$ rRNA gene similarity of $99.5 \%$, a value which corresponded to $7 \mathrm{nt}$ differences at 1438 locations. Strain M1463 ${ }^{\mathrm{T}}$ was also relatively closely related to Streptomyces indonesiensis DSM $41759^{\mathrm{T}}$ (98.8\% similarity, 17 nt differences), Streptomyces griseiniger NRRL B-1865 ${ }^{\mathrm{T}}$ (98.7\% similarity, $18 \mathrm{nt}$ differences) and Streptomyces cangkringensis DSM $41769^{\mathrm{T}}$ (98.6\% similarity, $19 \mathrm{nt}$ differences). All of these similarity values were below those recorded between the type strains of several species classified in the S. violaceusniger clade (Goodfellow et al., 2007; Kumar \& Goodfellow, 2008). Consequently, these results were in line with strain $\mathrm{M} 1463^{\mathrm{T}}$ being recognized as the type strain of a novel species.

The level of DNA-DNA relatedness between $\mathrm{M} 1463^{\mathrm{T}}$ and S. malaysiensis DSM $41697^{\mathrm{T}}$ was determined by measuring the divergence between the thermal denaturation midpoints of homologous and heterologous DNA preparations $\left(\Delta T_{\mathrm{m}}\right)$ following the procedure developed by Gonzalez \& Saiz-Jimenez (2005). In addition, the DNA G + C content of strain $\mathrm{M} 1463^{\mathrm{T}}$ was determined following the procedure used by these workers. The $\Delta T_{\mathrm{m}}$ value found between the DNA preparations of the two strains was $7.2{ }^{\circ} \mathrm{C}$, a result well above the cut-off point recommended for the delineation of genomic species $\left(\Delta T_{\mathrm{m}}>5{ }^{\circ} \mathrm{C}\right.$; Wayne et al., 1987) and one equivalent to a DNA relatedness value of just above $50 \% . \Delta T_{\mathrm{m}}$ values well below $7.2{ }^{\circ} \mathrm{C}$, but above $5{ }^{\circ} \mathrm{C}$, have been recorded between type strains of species assigned to the $S$. violaceusniger clade. The DNA G+C content of strain $\mathrm{M} 1463^{\mathrm{T}}$ was $71.8 \mathrm{~mol} \%$.

Strain $\mathrm{M} 1463^{\mathrm{T}}$ was also examined for a range of chemotaxonomic, colonial and other phenotypic features, the latter by using modified Bennett's agar (Jones, 1949) and standard ISP media (Shirling \& Gottlieb, 1966). All phenotypic features were examined using media and methods described by Williams et al. (1983). The dominant

Table 1. Phenotypic characteristics that distinguish strain $\mathrm{M}_{1463^{\top}}$ from related species of the genus Streptomyces

Strains: $1, \mathrm{M} 1463^{\mathrm{T}} ; 2$, S. malaysiensis DSM $41697^{\mathrm{T}}$ (data from Al-Tai et al., 1999); 3, S. indonesiensis DSM $41759^{\mathrm{T}}$ (Sembiring, 2000); 4, S. griseiniger DSM $41895^{\mathrm{T}}$ (Sembiring, 2000). All strains were positive for urea hydrolysis, nitrate reduction, degradation of casein, growth at $37^{\circ} \mathrm{C}$ and pH 5-10, utilization of fructose, galactose, glucose, mannitol, trehalose, melibiose and rhamnose as sole carbon sources, and utilization of L-alanine as sole carbon and nitrogen source. In contrast, they did not grow at 4 or $45{ }^{\circ} \mathrm{C}$, hydrolyse allantoin, degrade chitin, guanine or xanthine, use sucrose $(1 \%, \mathrm{w} / \mathrm{v})$, sodium citrate or sodium acetate as a sole carbon source $(0.1 \%, \mathrm{w} / \mathrm{v})$, or grow in the presence of neomycin sulphate $\left(30 \mu \mathrm{g} \mathrm{ml}^{-1}\right)$ or gentamicin sulphate $\left(10 \mu \mathrm{g} \mathrm{ml}^{-1}\right)$. +, Positive or utilized; - , negative or not utilized.

\begin{tabular}{|c|c|c|c|c|}
\hline Characteristic & 1 & 2 & 3 & 4 \\
\hline \multicolumn{5}{|l|}{ Degradation tests $(\%, \mathrm{w} / \mathrm{v})$} \\
\hline Aesculin hydrolysis $(0.1)$ & - & + & + & + \\
\hline Arbutin hydrolysis $(0.1)$ & + & - & + & + \\
\hline Gelatin (0.4) & - & + & + & + \\
\hline Hypoxanthine (0.4) & - & + & - & + \\
\hline L-Tyrosine $(0.4)$ & - & + & + & + \\
\hline RNA & - & - & + & - \\
\hline Tween $80(1.0)$ & + & + & - & - \\
\hline \multicolumn{5}{|l|}{ Growth on sole carbon sources $(\%, w / v)$} \\
\hline Adonitol (1.0) & - & + & + & + \\
\hline$(+)$-L-Arabinose (1.0) & + & + & + & - \\
\hline Cellobiose (1.0) & + & + & + & - \\
\hline Dextrin $(1.0)$ & + & + & + & - \\
\hline Lactose (1.0) & + & - & + & + \\
\hline Salicin (1.0) & - & + & + & + \\
\hline myo-Inositol (1.0) & - & + & + & + \\
\hline Raffinose (1.0) & - & + & + & + \\
\hline Xylose (1.0) & - & + & - & - \\
\hline Sodium propionate $(0.1)$ & - & + & - & + \\
\hline \multicolumn{5}{|c|}{ Growth on sole nitrogen sources $(0.1 \%, \mathrm{w} / \mathrm{v})$} \\
\hline L-Isoleucine & + & + & - & + \\
\hline L-Methionine & + & - & + & + \\
\hline L-Serine & + & + & - & + \\
\hline Growth at $\mathrm{pH} 4.0$ & - & + & + & + \\
\hline Growth in $8 \mu \mathrm{g}$ chloramphenicol $\mathrm{ml}^{-1}$ & + & - & + & - \\
\hline
\end{tabular}


diaminopimelic acid isomer was determined using the TLC system of Staneck \& Roberts (1974), albeit using a modified solvent system (methanol/ $\mathrm{H}_{2} \mathrm{O} / 10 \mathrm{M} \mathrm{HCl} / \mathrm{pyr}$ idine, $85: 15: 5: 10$, by vol.); menaquinones were extracted and purified following Collins (1985) and analysed by HPLC (Wu et al., 1989). Fatty acids were extracted, methylated and analysed by GC using the MIDI (Microbial ID) system (Sasser, 1990; Kämpfer \& Kroppenstedt, 1996). The organism contained LL-diaminopimelic acid as the diagnostic diamino acid in the cell-wall peptidoglycan, octahydrogenated menaquinones with nine isoprene units as the dominant isoprenologue and had a fatty acid profile rich in iso- and anteiso-fatty acids (iso- $\mathrm{C}_{15: 0}, 33.4 \%$; anteiso- $\left.\mathrm{C}_{15: 0}, 15.3 \% ; \mathrm{C}_{16: 0}, 10.9 \%\right)$, properties that are typical of streptomycetes (Manfio et al., 1995; Anderson \& Wellington, 2001). It can be seen from Table 1 that while strain $\mathrm{M} 1463^{\mathrm{T}}$ and S. malaysiensis DSM $14697^{\mathrm{T}}$ had properties in common, they can be readily distinguished by using a combination of biochemical and physiological features, i.e. strain $\mathrm{M} 1463^{\mathrm{T}}$, unlike S. malaysiensis DSM $14697^{\mathrm{T}}$, hydrolyses arbutin but does not hydrolyse aesculin, degrade gelatin, hypoxanthine or L-tyrosine, or grow on a range of sole carbon sources for energy and growth. The two strains can also be separated based on the colour of their aerial spore mass and substrate mycelia, and their ability to produce diffusible pigments on a range of organic media (Table 2).

Isolate $\mathrm{M} 1463^{\mathrm{T}}$ and the most related species of the genus Streptomyces were examined for a range of phenotypic markers using established procedures (Williams et al., 1983). A comparison of the phenotypic characteristics of

Table 2. Comparative growth and cultural characteristics of strain $M 1463^{\top}$ and related species of the genus Streptomyces

Taxa: 1, M1463 ${ }^{\mathrm{T}}$; 2, S. malaysiensis DSM $41697^{\mathrm{T}}$ (data from Al-Tai et al.,1999); 3, S. indonesiensis DSM 41759 ${ }^{\mathrm{T}}$ (Sembiring, 2000); 4, S. griseiniger DSM $41895^{\mathrm{T}}$ (Sembiring, 2000). +++ , Abundant growth; ++ , moderate growth; + , poor growth.

\begin{tabular}{|c|c|c|c|c|}
\hline Media & 1 & 2 & 3 & 4 \\
\hline \multicolumn{5}{|c|}{ Modified Bennett's agar } \\
\hline Growth & +++ & ++ & +++ & + \\
\hline Aerial mycelium & Grey & White & White & White \\
\hline Reverse colour & Yellow-green & Brown & Brown & Colourless \\
\hline Soluble pigment & None & Light brown & Brown & None \\
\hline \multicolumn{5}{|c|}{ Glucose-yeast extract-malt extract agar } \\
\hline Growth & +++ & +++ & + & +++ \\
\hline Aerial mycelium & Grey & Dark grey & Grey-white & White-grey \\
\hline Reverse colour & Yellow-brown & Brown-grey & Brown & Yellow \\
\hline Soluble pigment & None & Brown & Yellow & None \\
\hline \multicolumn{5}{|c|}{ Glycerol-asparagine agar (ISP 5) } \\
\hline Growth & ++ & + & ++ & ++ \\
\hline Aerial mycelium & Grey & White-grey & White & White \\
\hline Reverse colour & Brown & Pale yellow-grey & Light yellow & Colourless \\
\hline Soluble pigment & None & None & None & None \\
\hline \multicolumn{5}{|l|}{ Oatmeal agar (ISP 3) } \\
\hline Growth & +++ & +++ & +++ & +++ \\
\hline Aerial mycelium & Grey & Smoky black & Grey & Grey \\
\hline Reverse colour & Greyish yellow & Yellow-brown & Greyish yellow & Greyish yellow \\
\hline Soluble pigment & None & None & Yellow & None \\
\hline \multicolumn{5}{|c|}{ Inorganic salts-starch agar (ISP 4) } \\
\hline Growth & +++ & +++ & +++ & + \\
\hline Aerial mycelium & Grey & Smoky black & Brownish grey & Grey-white-black \\
\hline Reverse colour & Grey-green & Grey & Yellow & Yellow-orange \\
\hline Soluble pigment & None & Yellow & None & Orange \\
\hline \multicolumn{5}{|l|}{ Tyrosine agar (ISP 7) } \\
\hline Growth & +++ & +++ & ++ & ++ \\
\hline Aerial mycelium & Grey & Grey & Dark grey & White-grey \\
\hline Reverse colour & Brown & Brown & Brown & Brown \\
\hline Soluble pigment & None & Dark brown & None & None \\
\hline \multicolumn{5}{|c|}{ Yeast extract-malt extract agar (ISP 2) } \\
\hline Growth & +++ & +++ & + & +++ \\
\hline Aerial mycelium & Grey & Dark grey & White & White \\
\hline Reverse colour & Brown & Brown-grey & Brown & Yellow \\
\hline Soluble pigment & None & Brown & Light brown & Yellow \\
\hline
\end{tabular}


strain $\mathrm{M} 1463^{\mathrm{T}}$ and the most closely related Streptomyces species is shown in Table 1. It is clear from these comparisons that strain $\mathrm{M} 1463^{\mathrm{T}}$ differs phenotypically from the type strains of the three recognized Streptomyces species.

The genotypic and phenotypic data show that strain $\mathrm{M} 1463^{\mathrm{T}}$ merits recognition as a representative of a novel species of the $S$. violaceusniger clade. The name proposed for this taxon is Streptomyces samsunensis sp. nov.

\section{Description of Streptomyces samsunensis sp. nov.}

Streptomyces samsunensis (sam.sun.en'sis. N.L. masc. adj. samsunensis from Samsun, Turkey, the source of the organism).

Spore chains are spirals; the spore surface is rugose. Grows well on modified Bennett's, glucose-yeast extract-malt extract, glycerol-asparagine, inorganic salts-starch, tyrosine, yeast extract-malt extract, oatmeal and peptone-yeast extract-iron agars. On oatmeal agar, the aerial spore mass colour is grey, becoming black and moist when mature, the substrate mycelium is greyish yellow and diffusible pigments are not produced. Melanin pigments are not produced on either peptone-yeast extract-iron or tyrosine agars. Growth occurs between 15 and $37{ }^{\circ} \mathrm{C}$, but not at 4 or $45{ }^{\circ} \mathrm{C}$, and from $\mathrm{pH} 5.0$ to 10.0 , but not at $\mathrm{pH} 4.0$ or 11.0 . Degrades arbutin, casein, starch, and Tweens 20 and 80, but not adenine, aesculin, chitin, DNA, elastin, gelatin, guanine, hypoxanthine, L-tyrosine, RNA, xanthine or xylan. Utilizes cellobiose, (-)-D-fructose, ( + )-D-galactose, $(+)$-D-mannose, melezitose, trehalose, dextrin, maltose, Dmannitol, (+)-L-arabinose, (+)-L-rhamnose, L-glutamate and melibiose as sole carbon sources, but not adonitol, (+)-D-arabinose, (-)-D-sorbitol, inulin, (-)-L-sorbose, sucrose, myo-inositol, raffinose, sucrose, salicin, sodium propionate, xylitol or xylose. Utilizes glycine, L-alanine, Larginine, L-histidine, L-hydroxyproline, L-proline, L-serine, $\mathrm{L}$-threonine and L-isoleucine as sole nitrogen sources but not L-cysteine, L-methionine, L-valine, DL-phenylalanine or L-phenylalanine. Sensitive to streptomycin sulphate $\left(32 \mu \mathrm{g} \mathrm{ml}^{-1}\right)$. Antimicrobial activity is shown against Aspergillus niger (isolated strain), Bacillus licheniformis NRRL B-1001, Bacillus subtilis NRRL B-209, Candida albicans ATCC 10231, Listeria monocytogenes (medical isolate), Micrococcus luteus NRRL B-287 ${ }^{\mathrm{T}}$, Pseudomonas aeruginosa NRRL B-2679, Staphylococcus aureus ATCC 25923 and Streptomyces murinus ISP 5091, but not against Aspergillus flavus NRRL 1957, Escherichia coli ATCC 25922, Saccharomyces cerevisiae ATCC 9763 or Proteus vulgaris NRRL B-123. Additional phenotypic properties are shown in Tables 1 and 2 . The predominant fatty acids in wholeorganism methanolysates are iso- $\mathrm{C}_{15: 0}$, anteiso- $\mathrm{C}_{15: 0}$ and $\mathrm{C}_{16: 0}$.

The type strain is $\mathrm{M}_{1463^{\mathrm{T}}} \quad\left(=\mathrm{DSM} \quad 42010^{\mathrm{T}}=\mathrm{NRRL}\right.$ $\mathrm{B}-24803^{\mathrm{T}}$ ), isolated from the rhizosphere of Robinia pseudoacacia. The DNA G + C content of the type strain is $71.8 \mathrm{~mol} \%$. The species description is based on a single strain and hence serves as the type strain description.

\section{Acknowledgements}

This research was supported by The Basic Sciences Research Group (TBAG) of Scientific and Technological Research Council of Turkey (TUBITAK; project no. 106T029).

\section{References}

Al-Tai, A., Kim, B., Kim, S. B., Manfio, G. P. \& Goodfellow, M. (1999). Streptomyces malaysiensis sp. nov., a new streptomycete species with rugose, ornamented spores. Int J Syst Bacteriol 49, 1395-1402.

Anderson, A. S. \& Wellington, E. M. H. (2001). The taxonomy of Streptomyces and related genera. Int J Syst Evol Microbiol 51, 797814.

Chun, J. (1995). Computer assisted classification and identification of Actinomycetes. $\mathrm{PhD}$ thesis, Department of Microbiology, University of Newcastle, Newcastle upon Tyne, UK.

Chun, J. \& Goodfellow, M. (1995). A phylogenetic analysis of the genus Nocardia with 16S rRNA gene sequences. Int J Syst Bacteriol 45, 240-245.

Chun, J., Lee, J.-H., Jung, Y., Kim, M., Kim, S., Kim, B. K. \& Lim, Y.-W. (2007). EzTaxon: a web-based tool for the identification of prokaryotes based on $16 \mathrm{~S}$ ribosomal RNA gene sequences. Int J Syst Evol Microbiol 57, 2259-2261.

Collins, M. D. (1985). Analysis of isoprenoid quinones. Methods Microbiol 18, 329-366.

DSMZ (1998). Catalogue of Strains, 5th edn. Braunschweig: DSMZ.

Duangmal, K., Ward, A. C. \& Goodfellow, M. (2005). Selective isolation of members of the Streptomyces violaceoruber clade from soil. FEMS Microbiol Lett 245, 321-327.

Felsenstein, J. (1985). Confidence limits on phylogenies: an approach using the bootstrap. Evolution 39, 783-791.

Felsenstein, J. (1993). PHYLIP (phylogeny inference package), version 3.5c. Distributed by the author. Department of Genome Sciences, University of Washington, Seattle, USA.

Fitch, W. M. \& Margoliash, E. (1967). Construction of phylogenetic trees. Science 155, 279-284.

Gonzalez, J. M. \& Saiz-Jimenez, C. (2005). A simple fluorimetric method for the estimation of DNA-DNA relatedness between closely related microorganisms by thermal denaturation temperatures. Extremophiles 9, 75-79.

Goodfellow, M., Ferguson, E. V. \& Sanglier, J. J. (1992). Numerical classification and identification of Streptomyces species - a review. Gene 115, 225-233.

Goodfellow, M., Kumar, Y., Labeda, D. P. \& Sembiring, L. (2007). The Streptomyces violaceusniger clade: a home for streptomycetes with rugose ornamented spores. Antonie van Leeuwenhoek 92, 173-199.

Hayakawa, M., Yoshida, Y. \& limura, Y. (2004). Selective isolation of bioactive soil actinomycetes belonging to the Streptomyces violaceusniger phenotypic cluster. J Appl Microbiol 96, 973-981.

Jones, K. L. (1949). Fresh isolates of actinomycetes in which the presence of sporogenous aerial mycelia is a fluctuating characteristic. J Bacteriol 57, 141-145.

Jukes, T. H. \& Cantor, C. R. (1969). Evolution of protein molecules. In Mammalian Protein Metabolism, vol. 3, pp. 21-132. Edited by $\mathrm{H}$. N. Munro. New York: Academic Press. 
Kämpfer, P. \& Kroppenstedt, R. M. (1996). Numerical analysis of fatty acid patterns of coryneform bacteria and related taxa. Can J Microbiol 42, 989-1005.

Kelly, K. L. (1958). Centroid notations for the revised ISCC-NBC color name blocks. J Res Nat Bur Standards U S A 61, 427.

Kumar, Y. \& Goodfellow, M. (2008). Five new members of the Streptomyces violaceusniger $16 \mathrm{~S}$ rRNA gene clade: Streptomyces castelarensis sp. nov., comb. nov., Streptomyces himastatinicus sp. nov., Streptomyces mordarskii sp. nov., Streptomyces rapamycinicus sp. nov. and Streptomyces ruanii sp. nov. Int J Syst Evol Microbiol 58, 1369-1378.

Kumar, Y., Aiemsum-Ang, P., Ward, A. C. \& Goodfellow, M. (2007). Diversity and geographical distribution of members of the Streptomyces violaceusniger $16 \mathrm{~S}$ rRNA gene clade detected by cladespecific PCR primers. FEMS Microbiol Ecol 62, 54-63.

Küster, E. (1959). Outline of a comparative study of criteria used in characterization of the actinomycetes. Int Bull Bacteriol Nomencl Taxon 9, 97-104.

Labeda, D. P. \& Lyons, A. J. (1991). The Streptomyces violaceusniger cluster is heterogeneous in DNA relatedness among strains: emendation of the descriptions of Streptomyces violaceusniger and Streptomyces hygroscopicus. Int J Syst Bacteriol 41, 398-401.

Lane, D. J. (1991). 16S/23S rRNA sequencing. In Nucleic Acid Techniques in Bacterial Systematics, pp. 115-175. Edited by E. Stackebrandt \& M. Goodfellow. Chichester: Wiley.

Lanoot, B., Vancanneyt, M., Hoste, B., Vandemeulebroecke, K., Cnockaert, M. C., Dawyndt, P., Liu, Z., Huang, Y. \& Swings, J. (2005). Grouping of streptomycetes using 16S-ITS RFLP fingerprinting. Res Microbiol 156, 755-762.

Liu, Z., Shi, Y., Zhang, Y., Zhou, Z., Lu, Z., Li, W., Huang, Y., Rodríguez, C. \& Goodfellow, M. (2005). Classification of Streptomyces griseus (Krainsky 1914) Waksman and Henrici 1948 and related species and the transfer of 'Microstreptospora cinerea' to the genus Streptomyces as Streptomyces yanii sp. nov. Int J Syst Evol Microbiol 55, 1605-1610.

Manfio, G. P., Zakrzewska-Czerwinska, J., Atalan, E. \& Goodfellow, M. (1995). Towards minimal standards for the description of Streptomyces species. Biotekhnologia 7-8, 242-253.

National Bureau of Standards (1964). The ISCC-NBS Color Manual Charts Illustrated with Centroid Colors. Supplement to NBS Circular 553. Washington, DC: US Government Printing Office.

Pitcher, D. G., Saunders, N. A. \& Owen, R. J. (1989). Rapid extraction of bacterial genomic DNA with guanidium thiocyanate. Lett Appl Microbiol 8, 151-156.
Saintpierre, D., Amir, H., Pineau, R., Sembiring, L. \& Goodfellow, M. (2003). Streptomyces yatensis sp. nov., a novel bioactive streptomycete isolated from a New-Caledonian ultramafic soil. Antonie van Leeuwenhoek 83, 21-26.

Saitou, N. \& Nei, M. (1987). The neighbor-joining method: a new method for reconstructing phylogenetic trees. Mol Biol Evol 4, 406425.

Sasser, M. (1990). Identification of bacteria by gas chromatography of cellular fatty acids, MIDI Technical Note 101. Newark, DE: MIDI Inc.

Sembiring, L. (2000). Selective isolation and characterisation of Streptomycetes associated with the rhizosphere of the tropical legume, Paraserianthes falcataria (L) Nielsen. PhD thesis. University of Newcastle, Newcastle upon Tyne, UK.

Sembiring, L., Ward, A. C. \& Goodfellow, M. (2000). Selective isolation and characterisation of members of the Streptomyces violaceusniger clade associated with the roots of Paraserianthes falcataria. Antonie van Leeuwenhoek 78, 353-366.

Shirling, E. B. \& Gottlieb, D. (1966). Methods for characterization of Streptomyces species. Int J Syst Bacteriol 16, 313-340.

Staneck, J. L. \& Roberts, G. D. (1974). Simplified approach to identification of aerobic actinomycetes by thin-layer chromatography. Appl Microbiol 28, 226-231.

Ward, A. C. \& Goodfellow, M. (2004). Phylogeny and functionality: taxonomy as a roadmap to genes. In Microbial Diversity and Bioprospecting, pp. 288-313. Edited by A. T. Bull. Washington, DC: American Society for Microbiology.

Wayne, L. G., Brenner, D. J., Colwell, R. R., Grimont, P. A. D., Kandler, O., Krichevsky, M. I., Moore, L. H., Moore, W. E. C., Murray, R. G. E. \& other authors (1987). International Committee on Systematic Bacteriology. Report of the ad hoc committee on reconciliation of approaches to bacterial systematics. Int J Syst Bacteriol 37, 463-464.

Williams, S. T., Goodfellow, M., Alderson, G., Wellington, E. M. H., Sneath, P. H. A. \& Sackin, M. J. (1983). Numerical classification of Streptomyces and related genera. J Gen Microbiol 129, 17431813.

Wu, C., Lu, X., Qin, M., Wang, Y. \& Ruan, J. (1989). Analysis of menaquinone compound in microbial cells by HPLC. Microbiology [English translation of Microbiology (Beijing)] 16, 176-178.

Xu, C., Wang, L., Cui, Q., Huang, Y., Liu, Z., Zheng, G. \& Goodfellow, M. (2006). Neutrotolerant acidophilic Streptomyces species isolated from acidic soils in China: Streptomyces guanduensis sp. nov., Streptomyces paucisporeus sp. nov., Streptomyces rubidus sp. nov. and Streptomyces yanglinensis sp. nov. Int J Syst Evol Microbiol 56, 1109-1115. 